\title{
Immunological basis of differences in disease resistance in the chicken
}

\author{
Bereket ZeKarias ${ }^{\mathrm{a}, \mathrm{c} *}$, Agnes A.H.M. Ter HuUrne ${ }^{\mathrm{a}}$, \\ Wil J.M. LANDMAN ${ }^{\mathrm{b}}$, Johanna M.J. REBEL ${ }^{\mathrm{a}}$, \\ Jan M.A. POL ${ }^{\mathrm{a}}$, Erik GRUYS ${ }^{\mathrm{c}}$ \\ ${ }^{a}$ ID-Lelystad, Institute for Animal Science and Health, P.O. Box 65, 8200 AB Lelystad, \\ The Netherlands \\ b Animal Health Service, Poultry Health Centre, P.O. Box 9, 7400 AA Deventer, \\ The Netherlands \\ ${ }^{\mathrm{c}}$ Department of Pathology, Faculty of Veterinary Medicine, Utrecht University, P.O. Box 80.158, \\ 3508 TD Utrecht, The Netherlands
}

(Received 27 April 2001; accepted 18 October 2001)

\begin{abstract}
Genetic resistance to diseases is a multigenic trait governed mainly by the immune system and its interactions with many physiologic and environmental factors. In the adaptive immunity, $\mathrm{T}$ cell and $\mathrm{B}$ cell responses, the specific recognition of antigens and interactions between antigen presenting cells, T cells and B cells are crucial. It occurs through a network of mediator proteins such as the molecules of the major histocompatibility complex (MHC), T cell receptors, immunoglobulins and secreted proteins such as the cytokines and antibodies. The diversity of these proteins that mainly is due to an intrinsic polymorphism of the genes causes phenotypic variation in disease resistance. The well-known linkage of MHC polymorphism and Marek's disease resistance difference represents a classic model revealing immunological factors in resistance differences and diversity of mediator molecules. The molecular bases in any resistance variation to infectious pathogens are vaguely understood. This paper presents a review of the major immune mediators involved in resistance and susceptibility to infectious diseases and their functional mechanisms in the chicken. The genetic interaction of disease resistance with production traits and the environment is mentioned.
\end{abstract}

immunity / disease resistance / mhe / T cell receptor / immunoglobulin / cytokine

Résumé-Bases immunologiques des différences dans la résistance aux maladies chez le poulet. La résistance génétique aux maladies est un trait multigénique qui est surtout gouverné par le système immunitaire et ses interactions avec de nombreux facteurs physiologiques et environnementaux. Dans l'immunité acquise, les réponses des cellules $\mathrm{T}$ et $\mathrm{B}$, la reconnaissance spécifique des antigènes

* Correspondence and reprints

Tel.: (31) 320 238238; fax: (31) 320 238094; e-mail: B.Zekarias@id.wag-ur.nl 
et les interactions entre les cellules présentant des antigènes, les cellules $\mathrm{T}$ et $\mathrm{B}$, sont cruciales. Cela se produit à travers un réseau de protéines médiatrices telles que les molécules du complexe majeur d'histocompatibilité (CMH), les récepteurs des cellules T, les immunoglobulines et les protéines sécrétées telles que les cytokines et les anticorps. La diversité de ces protéines, qui est surtout due au polymorphisme intrinsèque des gènes, entraîne une variation phénotypique dans la résistance aux maladies. Le lien bien connu entre le polymorphisme du $\mathrm{CMH}$ et les différences dans la résistance à la maladie de Marek représente un modèle classique révélant les facteurs immunologiques dans les différences de résistance et la diversité dans les molécules médiatrices. Les bases moléculaires impliquées dans toute variation de résistance aux pathogènes infectieux sont à peu près comprises. Cet article présente une synthèse sur les principaux médiateurs de l'immunité impliqués dans la résistance et la sensibilité aux maladies infectieuses chez le poulet et leurs mécanismes fonctionnels. L'interaction génétique entre la résistance aux maladies et les traits de production et l'environnement est mentionnée.

immunité / résistance aux maladies / complexe majeur d'histocompatibilité / récepteur de la cellule T / immunoglobuline / cytokine

Table of contents

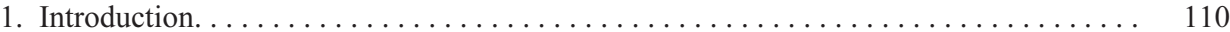

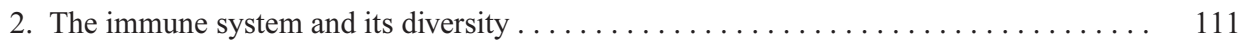

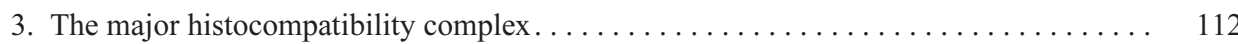

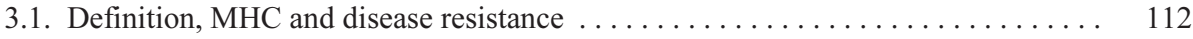

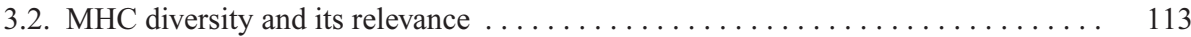

3.3. Functional mechanisms of the MHC in immune competence . . . . . . . . . . . . 114

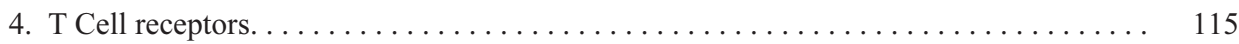

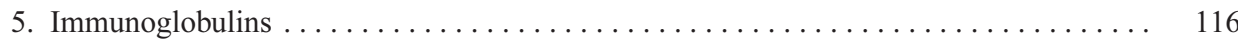

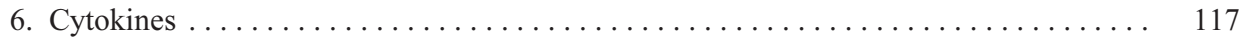

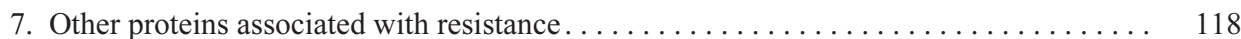

7.1. Natural resistance associated macrophage protein 1 (Nramp-1) . . . . . . . . 118

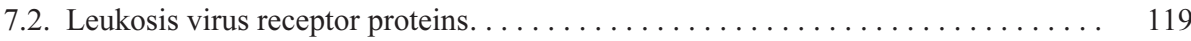

8. Interactions of disease resistance, production traits and the environment . . . . . . . . 119

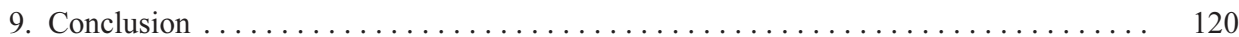

\section{INTRODUCTION}

In any outbred population, genetically determined difference in disease resistance or susceptibility between individuals is common. Some breeds or strains are inherently resistant or less affected by a pathogen that can be fatal to other members of the same species. Differences in disease resistance between strains of chickens have long been described [9, 59, 77]. Genetic resistance to diseases is a great resource for the control and prevention of diseases and to the improvement of productivity in poultry [5, 17, 32]. The advantages of genetic resistance have been emphasised by the emergence of virulent and drug-resistant pathogens, restrictions on the use of antimicrobials and the appearance of certain diseases associated with selection for production traits. In the past, the role of genetic resistance in disease control in poultry was limited because of the massive application of chemotherapeutics.

Genetically determined diversity of the immune system is the major cause for differences in resistance to diseases of infectious 
origin [41, 51]. A disease occurs if the immune system fails to protect the body from the injuries inflicted by the invading pathogen, due to insufficient-, misdirected- or aberrant immune responses. The immune response against infectious pathogens is an elaborate process and varies among individuals. The immune competence of the host could be evaluated using certain immune parameters such as the antibody production, lymphocyte proliferation, phagocyte activity, parasite load, etc. $[4,16,53]$. These immune parameters describe the immune responsiveness that could be correlated with resistance or susceptibility to a pathogen. Yet, it is essential to discern the molecular basis for variation in the immune response and disease resistance.

The immune response operates through interactions of the immune effector cells (leukocytes) with the invading pathogen, infected cells and cells that are committed in scavenging and duly presenting antigens to lymphocytes. The main immune effector cell types are the T cells, B cells and the antigen presenting cells (APC) [113]. The interaction between these cells that takes place by means of surface molecules, and secreted proteins are crucial [36]. The main mediators in the communication of the immune cells are membrane proteins such as molecules of the major histocompatibility complex (MHC), T cell receptors (TcR) and immunoglobulins (B cell receptors), and secreted proteins such as cytokines and antibodies [33, 51, 95]. These proteins are immune intermediaries involved in antigen binding and presentation, activating immune effector cells and linking the different events during the immune response. At the molecular level, a difference in immune competence could mainly be attributed to the efficacy of the immune mediator molecules and their diversity. These proteins are genetically diverse and polymorphic. The association between disease resistance or susceptibility and polymorphism of these proteins or their encoding genes has made them potential immunogenetic markers for resistance or susceptibility $[35,50]$. Due to the complexity of the immune system, the actual functional mechanism of each immune mediator protein and its marker significance in disease resistance is obscure.

In the chicken, the association between MHC polymorphism and resistance or susceptibility differences to infectious pathogens had long been recognised $[13,78]$. In most reports, the MHC is outlined in association to resistance or susceptibility to specific agents such as the Marek's disease virus (MDV). Yet, the role of the other immune mediator proteins and their immunogenetics in disease resistance difference are less described in chickens. This review highlights the immune modulator proteins with an outlook on innate differences in resistance to infectious diseases. Their functional mechanisms are discussed following a brief outline of the immune system. Finally, the interaction of disease resistance with production traits and the environment is addressed.

\section{THE IMMUNE SYSTEM AND ITS DIVERSITY}

The innate immunity is the first line of defence against invading pathogens. It includes inflammatory reaction, phagocytosis, acute phase reaction, complement proteins, etc. that are constitutional nonspecific defence reactions (Tab. I) [113]. The other compartment of the immune system, i.e., the adaptive immunity, is most involved in individual differences in resistance to infectious pathogens. The adaptive immune response mainly operate through communications of the APC, $T$ cells and $B$ cells by direct cell-to-cell contact using MHC, TcR and immunoglobulins and/or by secreted proteins such as cytokines in a paracrine way (Tab. I) [36, 51, 113]. The quantity and quality of the immune response depends on 
Table I. Compartments of the immune system, functional cell types, mediator proteins and functional characteristics of the system.

\begin{tabular}{|c|c|c|c|}
\hline $\begin{array}{l}\text { Compartments } \\
\text { of the immune } \\
\text { system }\end{array}$ & Cell types & Mediator proteins & Characteristics \\
\hline $\begin{array}{l}\text { Innate } \\
\text { immunity }\end{array}$ & $\begin{array}{l}\text { Leukocytes, } \\
\text { natural killer } \\
\text { cells }\end{array}$ & $\begin{array}{l}\text { Complement proteins, } \\
\text { acute phase proteins, } \\
\text { adhesion molecules, } \\
\text { radicals, oxides, } \\
\text { lysozymes, surfactants, } \\
\text { lectins }\end{array}$ & $\begin{array}{l}\text { Target non-specific, } \\
\text { triggered by danger signals, } \\
\text { initiate adaptive response }\end{array}$ \\
\hline $\begin{array}{l}\text { Adaptive } \\
\text { immunity }\end{array}$ & $\begin{array}{l}\text { Antigen } \\
\text { presenting cells, } \\
\text { B cells, T cells }\end{array}$ & $\begin{array}{l}\text { Major histocompatibility } \\
\text { complex, T cell } \\
\text { receptors, B cell } \\
\text { receptors, antibodies, } \\
\text { cytokines }\end{array}$ & $\begin{array}{l}\text { Target specific (qualitative } \\
\text { and quantitative), memory } \\
\text { function }\end{array}$ \\
\hline
\end{tabular}

the nature of the interaction of these molecules. For instance, the association between the MHC and TcR is decisive for T cell responses rather than a direct contact of the $\mathrm{T}$ cell $(\mathrm{TcR})$ with the pathogen or antigen.

Individual variation in immune response is linked to the structural and functional diversity of the MHC, TcR, immunoglobulins (antibodies), cytokines and certain other proteins $[1,51]$. These proteins are encoded by multiple and polymorphic genes $[35,50]$. The polymorphism and expression differences of the genes are mainly due to an intrinsic behaviour, but are also generated and maintained by mutations. The characteristic relation of the gene and its protein products in disease resistance has been mostly analysed in congenic and transgenic animals. The expression of the proteins could be analysed at protein level (proteomics), or RNA (microarrays) or DNA levels [25, 35]. Resistance marker genes or quantitative trait loci (QTL) might be identified through anonymous analysis of the whole genome such as by microsatellites. Yet, most of the known disease resistance QTL have been distinguished by using candidate gene approach targeting certain immune mediator proteins that are mentioned in the following sections.

\section{THE MAJOR HISTOCOMPATIBILITY COMPLEX}

\subsection{Definition, MHC and disease resistance}

The major histocompatibility complex (MHC), the B complex in the chicken, is composed of heterodimeric transmembrane glycoproteins that are essential in the presentation of antigens to T-lymphocytes (reviewed in $[72,106])$. The MHC molecules (class I, class II and class IV or $B-F$, $B-L$ and $B-G$, respectively), belong to the immunoglobulin superfamily with extracellular regions composed of two N-terminal antigen binding domains and two constant domains that bind to the analogous receptor molecules on the $\mathrm{T}$ cell membrane [106]. Class I molecules are present in all cell types. They are expressed with endogenously synthesised peptides including self-derived 
and viral peptides. Class II MHC is expressed by antigen presenting cells (APC) with processed exogenous antigens such as bacterial antigens. The class I and II MHC molecules are restriction molecules in APC - T cell $-\mathrm{B}$ cell interactions [113]. T cells identify antigenic peptides and are activated by recognising the MHC molecules expressed with the antigen on the surface of APC or infected cells [73].

The class IV MHC is so far exclusively reported in avian species. It has originally been established for expression on erythrocytes (reviewed in [68]) and later it was recognised that many other cell types also express the class IV MHC molecules, such as liver cells, bursal and thymic lymphoblast and stromal cells [118]. The class IV MHC is involved in antibody response, which is supposed to involve B cell repertoire and the $\mathrm{B}$ cell antigen recognition and binding [65]. The other unique MHC linked gene in the avian, is the $R f p-Y$ that is recognised by DNA restriction fragment pattern $(R f p)$ of the MHC class I, II and IV genes in one MHC haplotype [14]. Besides the location of the gene being contained within the MHC gene regions, its function is not clear.

In the chicken, the MHC is closely associated with resistance or susceptibility differences to a number of diseases [80]. A comprehensive review on the MHC linkage with differences in disease resistance has been given in several papers: resistance to viral infections $[18,42,66,88,104,133$, 137], resistance to bacterial infections [29, $46,122]$, resistance to protozoal infection $[21,86,129]$, and autoimmune diseases [114].

\subsection{MHC diversity and its relevance}

The MHC molecules are extremely diverse and are distinct between individual [98]. The diversity of $\mathrm{MHC}$ at a population level is due to the exceptional polymorphism of the genes encoding the class I, II and IV molecules [87]. The uniqueness of the MHC molecule in each individual makes the immune response to vary between the MHC haplotypes. Because the T cell response is restricted to MHC-bound antigenic fragments, the diversity of the MHC's antigen-binding region has crucial immunological consequences for the induction of the adaptive immune responses [79]. Thus, the multiplicity of MHC, mainly at the antigen-binding region, is crucial in order to cope with a range of antigenic peptides that could be encountered [87]. The properties of the MHC haplotype, regarding its affinity for a particular antigenic epitope, and the level of its expression have effect on $\mathrm{T}$ cell selection and activation [116].

Chickens have relatively few MHCgenes packed in a small region about $92-\mathrm{kb}$ long, which is only $5 \%$ of the corresponding mammalian MHC (class I and II) gene region [63]. Yet, the level of selection on individual alleles is higher in the chicken compared to the mammals, that have many highly expressed MHC class I and II genes. There are over $28 \mathrm{MHC}$ haplotypes in chickens distinguished by serology [12]. Each haplotype expresses one dominant class I MHC molecule with a different level of expression [67]. MHC heterozygous individuals with two different alleles have advantages over homozygous; nevertheless, in chickens, only two options for peptide-binding specificity (MHC antigens) are possible. The relatively simple and compact nature of the chicken MHC-gene that allows low level of recombination is presumed somehow to contribute to the MHC's strict association with resistance differences to certain infectious pathogens (reviewed in [64, 67]). Its smallness might create a window of variation, as life or death, between the haplotypes. The close correlation of MHC haplotypes with susceptibility differences to certain infections such as the MDV might have been a consequence of a parallel evolution of specific 
MHC haplotypes with important pathogens that eventually let the survival of a few haplotypes [64, 67].

Compared to the class I, II and IV gene regions only limited $R f p-Y$ polymorphism that contentiously correlated with differences in resistance to pathogens, especially MDV, has so far been reported [76, 132]. Nevertheless, the $R f p-Y$ polymorphism and its role in the MHC determined resistance and susceptibility to infectious pathogens, is a subject for further investigation.

\subsection{Functional mechanisms of the MHC in immune competence}

Until this time, the exact effect of $\mathrm{MHC}$ diversity on the differences in disease resistance and susceptibility remained obscure, besides the class I and II MHC molecules' role in restriction of the $\mathrm{T}$ cell receptor. The MHC-dependent resistance and susceptibility in chickens is presumed to depend on peptide-binding specificity of the dominantly expressed class I molecule [64]. This seems probable for resistance to smaller pathogens or those viruses that contain few peptides [66]. A good example is the MHC determined resistance and susceptibility to Rous sarcoma virus (RSV) wherein resistance is related to the presence of appropriate peptide binding class I MHC on the surface of affected (tumour) cells to be recognised by cytotoxic $\mathrm{CD}^{+} \mathrm{T}$ cells. The RSV resistant strains, such as the $\mathrm{CB}$ line, have MHC I molecules that effectively bind to the peptide derived from the viral src gene whereas in susceptible chicken, such as the CC line, no efficient binding (and presentation) of the peptide occurs [66, $120]$. On the other hand, in MDV that is perhaps the most explicit case regarding the linkage of $\mathrm{MHC}$ and disease resistance or susceptibility, the resistance differences between MHC haplotypes is related to the level of class I molecule expression rather than its specificity [67]. Chicken strains carrying MHC haplotypes that express less class I molecules, such as $B^{21}$ strains, are resistant to MDV, while those that abundantly express class I molecules, such as the $\mathrm{B}^{19}$, are most susceptible [42]. The mechanism for the linkage between resistance and less class I molecule expression is supposed to be by a NK cell recognition and activation at low MHC expression level. The role of the class IV MHC molecules in antibody response is speculated to be through enhancing the antigen recognition by $\mathrm{B}$ and $\mathrm{T}$ cells and in the selection of B cells. Class IV antigen is also presumed to play an adjuvant effect in antibody response against endogenous or exogenous antigen [118]. Class IV MHC haplotypes have divergent antibody responses that in effect can be linked with resistance differences to infectious pathogens attributed to difference in antibody production (see below, Sect. 5) [65]. There has been a conception that class IV molecules might be involved in enteric mucosal immunity against viruses, bacteria and protozoal infection and have a role as receptors in intestinal epithelial barrier cells where they are also expressed [97]. However, none of these functions of the class IV is persuasive.

Further, the MHC has an extensive regulatory effect on many immune response traits that elaborate its functional mechanisms in resistance and susceptibility differences. These include MHC involvement in antibody responses $[37,69,89]$, cytokine production [43], activity of cytotoxic and natural-killer (NK) cells [119]. For instance, the MHC haplotype lines that are resistant to MDV and RSV have enhanced NK cell activity attributed to higher expression of the MHC-linked NK receptor-1 gene (NK-r1) [81]. The MHC haplotypes also show a difference in $\mathrm{T}$ cell proliferation [127], serum complement proteins [23], chemotactic activity of mononuclear leukocytes [109] and macrophage effector functions such as phagocytosis, bacterial killing, respiratory burst and nitric oxide synthesis [107]. Furthermore, the MHC 
gene is known to regulate the amount and proportion of $\mathrm{T}$ cell sub-populations such as the $\mathrm{CD}^{+}$and $\mathrm{CD}^{+} \mathrm{T}$ cells present in the blood and peripheral tissues $[39,48]$. The incidence of other $\mathrm{MHC}$ related genes contained within the MHC-gene region such as the lectin gene, Tap2 (transporter associated with antigen processing) and NK-r1, perhaps contribute in the classical MHC haplotype linked differences in immune responses and disease resistance.

\section{T CELL RECEPTORS}

$\mathrm{T}$ cell receptors $(\mathrm{TcR})$ are multichain transmembrane heterodimers, consisting of $\alpha$ and $\beta$ or $\gamma$ and $\delta$ chains that are non-covalently associated with an invariable CD3 molecule $[24,73]$. The TcR is the antigen recognising molecule of $\mathrm{T}$ cells that binds with the MHC presented with the antigenic peptide on the surface of APC or infected cells. Consequently, the $\mathrm{T}$ cells are activated and differentiate into effector and/or regulator cell types.

The MHC binding region of the TcR is highly polymorphic and each circulating $\mathrm{T}$ cell has a unique TcR $[31,73]$. The presence of a range of $T$ cells having different $\mathrm{TcR}$ is vital to counter the numerous possible MHC-antigen complexes. The diversity of TcR likely influences the immune responsiveness and disease resistance. There are few studies in human [101] and sheep [11] that indicate an association between the polymorphism of TcR and a difference in disease resistance. The diversity of TcR is due to the presence of multiple TcRgenes that are generated by a process called gene rearrangement, that is a random recombination (shuffling) of the genes for the variable $(\mathrm{V})$, the diversity (D) (of $\beta$ chain) and the joining $(\mathrm{J})$ segment of the TcR-gene [31]. By the V- (D)- J gene recombination, numerous genes for the $\alpha, \beta, \gamma$ and $\delta$ TcR chains are generated. Unfortunately, the chickens have relatively few $\mathrm{V}, \mathrm{D}$ and $\mathrm{J}$ genes and this seems to limit TcR diversity compared with mice in which more than $10^{15} \alpha \beta \mathrm{TcR}$ heterodimers are estimated [128]. This lower TcR diversity in the chicken might be an evolutionary consequence of the presence of fewer MHC mol ecules. Nevertheless, chickens are still capable of making numerous TcR heterodimers [24].

The $\alpha \beta T c R$ expressing $T$ cells are the main types of effector cells in the chicken [24]. The different sub-populations of the $\alpha \beta$ T cells, such as those differentiated by the $\mathrm{V}$ region of the $\beta$ chain, $\mathrm{V} \beta 1^{+}$(TCR2) or $\mathrm{V} \beta 2^{+}$(TCR3) [75], or by the accessory receptor molecules $\mathrm{CD}^{+}$or $\mathrm{CD}^{+}$[92], have distinct functional activities [3, 26]. The amount and proportion of the $\mathrm{T}$ cell sub-populations in blood and in peripheral tissues have been correlated with differences in disease susceptibility $[135,139]$. Quantitative and/or qualitative alterations in T cells sub-population could influence immune competence and resistance differences against infectious pathogens and certain autoimmune diseases such as scleroderma [135] and thyroiditis [27]. In scleroderma, a fibrotic disease, susceptible chickens have low numbers of $\mathrm{CD}^{+} \mathrm{T}$ cells and defective $\mathrm{T}$ cell activation that partly is attributed to a defect in TcR mediated activation and/or accessory in the CD28 (homologue) molecules. In strains susceptible to autoimmune thyroiditis, such as the OS strain, a selective depletion of the V $\beta 1 \mathrm{~T}$ cells, mainly the $\mathrm{CD}^{+}$cells, prevents the disease which indicates a preferential involvement of the TcR V $\beta 1$ gene. A higher number of $\mathrm{CD}^{+} \mathrm{T}$ cells or the percentage in comparison with $\mathrm{CD}^{+} \mathrm{T}$ cells in blood, thymus or spleen has immunomodulatory significance often correlated with a wide-ranging immune competence $[38,102]$. In broiler chicken lines that differ in the susceptibility to malabsorption-syndrome associated to enteric infections, a difference in the amount of resident $\mathrm{CD}^{+} \mathrm{T}$ cells and $\mathrm{CD} 8^{+} \mathrm{T}$ cells in intestinal mucosa (villi) have been observed (Zekarias and ter Huurne, unpublished results). 
There were more $\mathrm{CD}^{+} \mathrm{T}$ cells present in the intestinal villi of broiler lines that are susceptible to malabsorption- syndrome compared to resistant lines. Similarly, a CD4 $4^{+}$cell dominated mucosal $\mathrm{T}$ cell response has been reported in chicken strains resistant to coccidiosis, whereas the susceptible lines have abundant $\mathrm{CD} 8^{+}$cells in the gut-associated lymphatic tissue $[85,139]$. In contrast, a $\mathrm{CD}^{+} \mathrm{T}$ cell biased response is predominant in chickens that are resistant to salmonella infection and have higher response to vaccination [10]. In white leghorns that are resistant to Enterococcus faecalis-induced amyloid arthropathy, a form of reactive amyloidosis, we observed a higher number of $\mathrm{CD}^{+} \mathrm{T}$ cells in the joints and in the peripheral blood than in the susceptible brown layer breeds [140]. The association of resistance and susceptibility with the amount or proportion of $\mathrm{CD}^{+} \mathrm{T}$ cells and $\mathrm{CD} 8^{+}$ $\mathrm{T}$ cells appear not coherent to a specific type of infectious pathogens. The immune competence correlated to a higher number of $\mathrm{CD}^{+} \mathrm{T}$ cell might likely represent a resistance against non-intracellular pathogens and antibody dominated response to antigens whereas $\mathrm{CD} 8^{+} \mathrm{T}$ cells might have significance in viral and intracellular infections that mainly require a cell mediated response. In turkeys, the presence of a higher number of $\mathrm{CD}^{+}$(or helper) $\mathrm{T}$ cells than $\mathrm{CD}^{+}$(or cytotoxic) $\mathrm{T}$ cells in the blood is associated with higher susceptibility to infections with Erysipelothrix rhusiopathiae, Pasteurella multocida and Newcastle disease virus [8, 84]. Some studies in turkeys also correlate the susceptibility differences to erysipelas, pasteurella, and Newcastle infections with polymorphism of the CD8 molecule [83]. Although not yet justified for its linkage with resistance or susceptibility to any pathogen, polymorphism of the CD8 molecule is more common in the chicken than in other species [93]. The significance of the $\mathrm{CD}^{+}$and $\mathrm{CD}^{+}{ }^{+} \mathrm{TcR}$ molecules in differences in immune competence and disease resistance is perhaps related to their role in restricting the reactivity of the TcR towards either of the MHC classes (I or II) and thereby determining the pattern of the immune reaction towards either a helper cell or cytotoxic cell dominated response.

\section{IMMUNOGLOBULINS}

Immunoglobulins are the major antigen recognising proteins that can bind with free antigenic peptides and are most essential in the ultimate elimination of pathogens [113]. Immunoglobulins are membrane receptor proteins on the $\mathrm{B}$ cell membrane or secreted into circulation and mucosal surfaces by plasma cells as antibodies. The diversity and the amount (quantity) of immunoglobulins are important factors in resistance and susceptibility to infectious pathogens [19]. The capability to produce large amounts and varied types of antibodies is often correlated with immune competence. For instance, the predisposition of bursectomised young chicks to a wide range of infectious agents seems largely an attribute of a lack of adequate antibody production or concentration [103].

There is a genetic difference in level of antibody responses, which is mainly controlled by the immunoglobulin-genes [19, 111]. Chicken strains have been categorised as high antibody responders (HA) or low antibody responders (LA) depending on the amount of circulating antibodies they produce against a given antigen [82, 121]. The most commonly used antigen for selection for HA and HL lines is sheep red blood cells [130]. The HA and LA lines show differences in susceptibility or resistance to pathogens. The HA chickens in most cases appear better protected to experimental infections with certain pathogens such as the Newcastle disease virus, Mycoplasma gallisepticum, Salmonella enteritidis, and Escherichia coli, than the LA lines $[45,136]$. The HA and LA also show difference in $\mathrm{T}$ cell responses; for 
instance, the HA lines have a high percentage of $\mathrm{CD}^{+} \mathrm{T}$ cells, while the LA lines have more $\mathrm{CD} 8^{+} \mathrm{T}$ cells in the spleen and thymus [102]. The LA chickens show an enhanced cellular response characterised by $\mathrm{T}$ cell proliferation and macrophage activity that could improve their resistance to intracellular bacteria and some viruses such as MDV in which antibodies are of less importance [43, 104]. The difference in the other immune parameters such as macrophage activity [71] and in preferential T cell responses and proliferation [43] and perhaps the antibody response itself, might possibly be related to the discrepancy in cytokine responses in HA and LA lines. In HA lines the Th2 cytokine responses are supposed to be predominant and the Th1 cytokine responses likely characterise the LA lines. This difference in cytokine responses (discussed in the following section) could explain the difference in disease resistance in conjunction with the difference in the humoral antibody response.

Several different antibodies each having different specificity and affinity are produced during infection [19]. The diversification of the antibodies produced during infection is another factor in immune competence. Antibody diversity is a result of the multiplicity of the genes encoding for the heavy $\left(\mathrm{V}_{\mathrm{H}}\right)$ and light $\left(\mathrm{V}_{\mathrm{L}}\right)$ immunoglobulin chains that are generated by $\mathrm{V}-(\mathrm{D})-\mathrm{J}$ gene rearrangements in the progenitor $B$ cells (reviewed in [110, 112]). Several hundreds of genes for the variable ' $V$ ' region of the $\mathrm{V}_{\mathrm{H}}$ and $\mathrm{V}_{\mathrm{L}}$ are formed by the random recombination of the $\mathrm{V}-\mathrm{D}\left(\right.$ for $\left.\mathrm{V}_{\mathrm{H}}\right)$ - J genes. Chickens have relatively few functional $V_{L}$ and $\mathrm{V}_{\mathrm{H}}$ genes; yet, they are capable of generating millions of different immunoglobulin producing B cell repertoire [110]. In the chicken, an additional diversification occurs in the bursa by a process of gene conversion [112]. In contrast to gene rearrangement that is initiated early during $\mathrm{B}$ cell ontogeny, diversification by gene conversion is influenced by the bursal microenvironment where the progenitor $\mathrm{B}$ cells that colonised the bursa as of 10 days embryonic age undergo proliferation and differentiation into functional cells. Malfunction in signalling the V-gene modification and clonal selection for the functional immunoglobulin genes in the bursa would severely limit the diversification of antibodies and $\mathrm{B}$ cell repertoires.

The process of V- (D)-J gene rearrangement is controlled by a recombinase enzyme encoded by the recombination activating genes (RAG1 and RAG2). In mice, a genetic defect of RAG would cancel immunoglobulin and TcR diversity as well as the maturation of $\mathrm{B}$ cells and $\mathrm{T}$ cells thereby diminishes disease resistance [99]. To our knowledge, there is hardly any specific disease to which resistance or susceptibility is linked to B cell repertoire or antibody diversity in the chicken. The effect of external antigens (pathogens) on immunoglobulin diversification is questionable. Yet, there are indications that presence of antigen or infection affects the eventual $\mathrm{B}$ cell proliferation and repertoire and has modest effect on $\mathrm{B}$ cell diversification [112]. Chickens that are bursectomized at early embryonic age of about 3 days have profoundly reduced antibody diversity and $\mathrm{B}$ cell repertoire [96]. In these chickens, the level of antibody in the serum might remain unaffected, but anticipated to be monoclonal. This might also attribute the susceptibility of such chickens to many infectious agents.

\section{CYTOKINES}

Cytokines are important molecules that mediate and orchestrate the complex events in the immune reaction, from the initiation of the acute phase reaction to the clonal expansion of effector T and B cells [94]. They are small glycoproteins (below $30 \mathrm{kDa}$ ) produced by various cells, particularly macrophages and $\mathrm{CD}^{+} \mathrm{T}$ cells are the main 
sources $[61,70]$. In the mouse, two main cytokine families, Th1 and Th2, are produced by the helper $\left(\mathrm{CD}^{+}\right) \mathrm{T}$ cells $[60,94$, 126]. These two cytokine categories essentially determine the pattern of the immune response. The Th1 cytokines include the interferon- $\gamma$ (IFN- $\gamma$ ), interleukin-2 (IL-2) and IL-12 that promote cell-mediated responses by cytotoxic $\mathrm{T}$ cells and macrophage activation. On the other hand, the Th2 cytokines such as IL-4, IL-5, IL-6 and IL-10 stimulate the humoral (antibody) response [60]. The differentiation of a progenitor $\mathrm{T}$ helper cell into the Th1 or Th2 helper cell has a critical impact on the pattern of immune response and subsequently on disease development [40, 54]. The initial priming of the resting $\mathrm{T}$ helper cell (Th0) occurs by the cytokines released instantly by phagocytes (macrophages) during infection. The type of antigen, the type of APC, the nature of cytokine gene expression and the memory response all influence Th phenotype selection into Th1 or Th2 [47]. When IL-12 is dominant, Th0 will differentiate into Th1 and in contrast, if IL- 4 is in abundance it promotes the differentiation into the Th2 phenotype $[60,123]$.

A clear correlation between types of cytokine response and differences in disease resistance has only been established in mice especially with the prototypic difference in resistance to Leishmania major infection [52]. The resistant mice strains have a higher Th1 response characterised by IL-12 and IFN- $\gamma$ production, whereas the susceptible strains are deficient in IL-12. In chickens, the Th1/Th2 cytokine dichotomy and difference in cytokine responses in correlation with disease resistance or susceptibility are still not well established. A Th1-like response characterised by IFN- $\gamma$ production has been shown in chickens resistant to MDV, Infectious Bronchitis, Newcastle disease and salmonellosis [56, $61,91]$. There is a correlation between resistance to these diseases and early and higher IFN- $\gamma$ production. A high level of IFN- $\gamma$ production has also been shown in chicken strains that are resistant to coccidiosis $[20,90,139]$. These observations suggest that chicken lines with an enhanced IFN- $\gamma$ response are more resistant to some viral and parasitic infections. Functionally, IFN- $\gamma$ is known to enhance macrophage activity and expression of $\mathrm{MHC}$, to increase the activity of cytotoxic T cells and the secretion of the Th1 cytokines [62]. Lowenthal et al. [91] have shown that treatment with recombinant IFN- $\gamma$ enhances resistance against coccidial infections and increases vaccine response.

\section{OTHER PROTEINS ASSOCIATED WITH RESISTANCE}

\subsection{Natural resistance associated macrophage protein 1 (Nramp-1)}

Nramp-1 is a membrane phosphoglycoprotein of macrophages that is involved in resistance to intracellular bacterial infections [22, 131]. Originally, it was designated as $B c g / L s h / I t y$ in mice for its association with resistance to mycobacterium, leishmania and salmonella infections [124]. The actual immunological function of Nramp-1 is not clear except for some indications that it inhibits bacterial growth in reticuloendothelial tissues in an early phase of infection. The mechanism is supposed to operate by modulation of the cytocidal activity of macrophages by enhancing the production of nitric oxide, phagolysosomal fusion, cytokine production and expression of class II MHC molecules $[6,46]$. There is a link between Nramp-1 polymorphism and differences in mortality after salmonella infection in the chicken [57]. About eleven sequence variations within the Nramp-1 gene have been identified that are closely associated with the differences in resistance to salmonellosis [58]. Amongst 
these, one sequence variant, an Arg. to Gln. replacement at amino acid residue 223 , was more frequent in the susceptible chickens. Other gene loci with a similar role as the Nramp-1 gene are the Sal-1 [134], and Tnc gene [58]. The functional identity of these genes and their protein products need to be further investigated.

\subsection{Leukosis virus receptor proteins}

There is a difference in the susceptibility to Avian Leukosis virus (ALV) infection that is correlated with the concentration of certain virus receptor proteins on the cell membrane [138]. ALV uses certain membrane proteins as receptor sites to attach and get access into the cell. The main receptor proteins are those designated as Tva receptors for ALV subtype A (ALV-A), CAR1 for subtypes B \& D, and SEAR for subtype $\mathrm{E}[2,15,55]$. These proteins are encoded by autosomal genes called tumour virus (Tv) genes [7]. Chicken strains that express many specific receptors on their cell surface are susceptible to the corresponding ALV subtype. By transgenics of the $T v$-gene, chicken lines resistant to ALV-A have been produced, which is so far a decent model in the application of transgenics for disease resistance [55]. In another mechanism, the receptor sites could be saturated with endogenously synthesised viral glycoproteins from endogenous retroviral genes (ev-genes) [30]. Such receptor interference by $e v$-genes could prohibit the admission of exogenous viruses. Some ev-genes express viral envelope glycoproteins like gp 85, which block the receptor sites evoking resistance against exogenous infection with the ALV subtype that needs the specific receptor [30]. Such receptor saturation or blockage also limits the congenital transmission of the virus [125]. For instance, the ev6-carrying chicken lines express ALV-E envelope glycoproteins and so are resistant to ALV subtype E infection [125].

\section{INTERACTIONS OF DISEASE RESISTANCE, PRODUCTION TRAITS AND THE ENVIRONMENT}

Disease resistance is a phenotypic expression of immunogenetics that simultaneously is subjected to interactions with several non-immune traits and the environment [44]. Production traits of commercial importance are often reviled for negative correlation with innate disease resistance $[105,108]$. For instance, the faster growth rate in meat type chickens and turkeys has adversely affected their immune competence against many infectious diseases [ 49 , $100,117]$. This has raised a controversy on the ongoing rigorous selection in poultry. Unfortunately, strains with better genetic resistance are in most cases poor producers; for example, leukosis resistance and egg yield. Perhaps an exception is the correlation of MDV resistance and egg production [74]. It seems that most production traits develop at the expense of the energy that would have been used for the immune physiology.

The environment includes factors such as husbandry, nutrition, hygiene and all other management practices. The immune responsiveness and disease resistance would be affected positively or negatively by the interactions with these external factors [34]. Genetic resistance could be diminished due to a sub-optimal immune response because of an unreceptive environment. Most of the time, selection for specific production trait is carried in a confined pathogen free environment that might permit a maximum expression of the production traits; yet, such environment biases the genetics of the immune competence and its actual interactions with the environment. Besides, a pathogen free 'optimal environment' condition is hardly achievable under practical farming situations.

The genetics of resistance is strengthened in a challenging environment, whereas a 
pathogen free condition diminishes the expression and development of genetic resistance [115]. This appears to be the rationale in Cole's observation [28] that is after exposing a parental flock to MDV, two lines emerged at the fourth generation: one line resistant and the other susceptible to experimental infection with MDV. The resistant line was less affected by the experimental challenge; in contrast, the other line suffered severe disease. The resistance of strains or breeds that are originally from areas where a disease is endemic is related to the immune system's adaptation to the challenge. In this regard, crossbreeding of strains of divergent origin could be a better compromise to maintain and develop genetic resistance from deteriorating due to selection under a non-challenging environment.

\section{CONCLUSION}

Improving the genetics of disease resistance is the most eligible approach for sustainable control of infectious diseases in poultry. The evolution of virulent infectious pathogens and the limitations on the use of chemotherapeutics, emphasise the advantage of breeding for genetic resistance. In order to develop the genetics of disease resistance, it is eminent to recognise the immunological elements are liable for natural resistance differences. A difference in disease resistance between individuals is the result of genetic heterogeneity of the immune response. The diversity of the $\mathrm{MHC}$, TcR, immunoglobulins and cytokines, constitutes the major immunological bases in resistance variations. The diversity of these molecules is attributed mainly to the intrinsic polymorphism of their genes. The MHC has been shown as a major immune factor associated with resistance differences to many infectious pathogens. Its broad effect on the various immune response features such as antibody responses, cytokine production, and TcR expression would elabo- rate its significance in disease resistance differences. By using congenic or transgenic chickens, the characteristic effect and the mechanisms of the various immune mediator proteins might be better elucidated.

The identification of disease resistance variation linked to immunologic traits and genes/QTL would advance the development of resistance markers and genetic engineering for disease resistance. A markerassisted selection by introgression of the resistance QTL is the most attractive approach to develop the genetic resistance. The immune system counteracts each pathogen with a distinct way. Therefore, an optimal improvisation of the immune competence by simultaneously considering different markers is essential to upgrade the general resistance to a range of pathogens. The immune mediators are also the best targets for vaccine and therapeutic interventions to enhance disease resistance. Finally, the eminent effect of genetic interactions of the immune physiology with certain non-immune related (production) traits and the environment on disease resistance needs to be taken into account in a global strategy.

\section{REFERENCES}

[1] Adams L.G., Templeton J.W., Genetic resistance to bacterial diseases of animals, Rev. Sci. Tech. Off. Int. Epizoot. 17 (1998) 200-219.

[2] Adkins H.B., Brojatsch J., Naughton J., Roll M.M., Pesola J.M., Young J.A.T., Identification of a cellular receptor for subgroup $\mathrm{E}$ avian leukosis virus, Proc. Natl. Acad. Sci. USA 94 (1997) 11617-11622.

[3] Arstila T.P., Vainio O., Lassila O., Central role of $\mathrm{CD}^{+}{ }^{+} \mathrm{T}$ cells in Avian Immune response, Poult. Sci. 73 (1994) 1019-1026.

[4] Bacon L.D., Measurement of immune competence in chickens, Poult. Sci. Rev. 4 (1992) 187-195.

[5] Bacon L.D., Hunt H.D., Cheng H.H., A review of the development of chicken lines to resolve genes determining resistance to diseases, Poult. Sci. 79 (2000) 1082-1093.

[6] Barton C.H., Whitehead S.H., Blackwell J.M., Nramp transfection transfers Ity/Lsh/Bcg-related 
pleiotropic effects on macrophage activation: influence on oxidative burst and nitric oxide pathways, Mol. Med. Cambridge, 1 (1995) 267-279.

[7] Bates P., Rong L., Varmus H.E., Young J.A.T., Crittenden L.B., Genetic mapping of the cloned subgroup A avian sarcoma and leukosis virus receptor gene to the TVA locus, J. Virol. 72 (1998) 2505-2508.

[8] Bayyari G.R., Huff W.E., Rath N.C., Balog J.M., Newberry L.A., Villines J.D., Skeeles J.K., Anthony N.B., Nestor K.E., Effect of the genetic selection of turkeys for increased body weight and egg production on immune and physiological responses, Poult. Sci. 76 (1997) 289-296.

[9] Bearse G.E., McClary C.F., Miller M.W., The results of eight years' selection for disease resistance and susceptibility in white Leghorns, Poult. Sci. 18 (1939) 4000-4401.

[10] Berndt A., Methner U., Gamma/delta T cell response of chickens after oral administration of attenuated and non-attenuated Salmonella typhimurium strains, Vet. Immunol. Immunopathol. 78 (2001) 143-161.

[11] Blattman A.N., Beh K.J., T-cell receptor and immunoglobulin gene polymorphism and resistance to Haemonchus contortus in sheep, J. Anim. Breed. Genet. 111 (1994) 65-74.

[12] Briles W.E., Briles R.W., Identification of haplotypes of the chicken major histocompatibility complex (B), Immunogenetics 15 (1982) 449-459.

[13] Briles W.E., Stone H.A, Cole R.K., Marek's disease: effects of B histocompatibility alloalleles in resistant and susceptible chicken lines, Science 14 (1977) 193-195.

[14] Briles W.E., Goto R.M., Auffray C., Miller M.M., A polymorphic system related to but genetically independent of the chicken major histocompatibility complex, Immunogenetics 37 (1993) 408-414.

[15] Brojatsch J., Naughton J., Rolls M.M., Zingler K., Young J.A.T., CAR1 a TNFR-related protein, is a cellular receptor for cytopathic avian leukosis-sarcoma viruses and mediates apoptosis, Cell 87 (1996) 845-855.

[16] Bumstead J.M., Bumstead N., Rothwell L., Tomley F.M., Comparison of immune responses in inbred lines of chickens to Eimeria maxima and Eimeria tenella, Parasitology 111 (1995) 143-151.

[17] Bumstead N., Breeding for disease resistance, in: Davison T.F., Morris T.R., Payne L.N. (Eds.), Poultry Immunology, Carfax Press, Abingdon, 1996, pp. 405-415.

[18] Bumstead N., Genetic resistance to avian viruses, Rev. Sci. Tech. Off. Int. Epizoot. 17 (1998) 249-255.
[19] Butler J.E., Immunoglobulin diversity, B cell and antibody repertoire development in large farm animals, Rev. Sci. Tech. Off. Int. Epizoot. 17 (1998) 43-70.

[20] Byrnes S., Emerson K., Kogut M., Dynamics of cytokine production during coccidial infections in chickens: colony-stimulating factors and interferon, FEMS Immunol. Med. Microbiol. 6(1993) 45-52.

[21] Caron L.A., Abplanalp H., Taylor R.L. Jr., Resistance, susceptibility, and immunity to Eimeria tenella in major histocompatibility (B) complex congenic lines, Poult. Sci. 76 (1997) 677-682.

[22] Cellier M., Belouchi A., Gros P., Resistance to intracellular infections: comparative genomic analysis of Nramp, Trends Genet. 12 (1996) 201-204.

[23] Chanh T.C., Benedict A.A., Abplanalp H., Association of serum haemolytic complement levels with the major histocompatibility complex in chickens, J. Exp. Med. 144 (1976) 555-561.

[24] Chen C.H., Göbel T.W.F., Kubota T., Cooper M.D., T cell development in the chicken, Poult. Sci. 73 (1994) 1012-1018.

[25] Cheng S., Rothschild M.F., Lamont S.J., Estimates of quantitative genetic parameters of immunological traits in the chicken, Poult. Sci. 70 (1991) 2023-2027.

[26] Cihak J., Hoffmann F.G., Ziegler H.H.W., Stein H., Kaspers B., Chen C.H., Cooper M.D., Losch U., T cells expressing the V beta $1 \mathrm{~T}$-cell receptor are required for $\mathrm{IgA}$ production in the chicken, Proc. Natl. Acad. Sci. USA 88 (1991) 1095110955.

[27] Cihak J., Hoffmann F.G., Wasl M., Markle H., Kaspers B., Hála K., Plachy J., Wick G., Prevention of spontaneous autoimmune thyroiditis in the Obese strain (OS) chickens by treatment with a monoclonal anti-CD4 antibody, J. Vet. Med. 43 (1996) 211-216.

[28] Cole R.K., The genetics of resistance to Marek's disease. in: Biggs P.M., Ce-Thé G., Payne I. (Eds.), Oncogenesis and herpesviruses, IARC Scientific Publications, Geneva, 1972, pp. 123128 .

[29] Cotter P.F., Taylor R.L. Jr., Abplanalp H., Differential resistance to Staphylococcus aureus challenge in major histocompatibility (B) complex congenic lines, Poult. Sci. 71 (1992) 1873-1878.

[30] Crittenden L.B., Retroviral elements in the genome of the chicken: implications for poultry genetics and breeding, Crit. Rev. Poult. Biol. 3 (1991) 73-109.

[31] Davis M.M., Bjorkman P.J., T-cell antigen receptor genes and T-cell recognition, Nature 334 (1988) 395-402 (erratum 335 (1988) 744).

[32] Delany M.E., Pisenti J.M., Conservation of poultry genetic research resources: consideration of the past, present and future, Poult. Avian Biol. Rev. 9 (1999) 25-42. 
[33] Dietert R.R., The major histocompatibility complex as a communication gene complex, Poult. Sci. 66 (1987) 774-775.

[34] Dietert R.R., Golemboski K.A., Austic R.E., Environment-immune interactions, Poult. Sci. 73 (1994) 1062-1076.

[35] Dodgson J.B., Cheng H.H., Okimoto R., DNA marker technology: a revolution in animal genetics, Poult. Sci. 76 (1997) 1108-1111.

[36] Doenhoff M.J., The immune system, in: Axford R.F.E., Bishop S.C., Nicholas F.W., Owen J.B. (Eds.), Breeding for disease resistance in farm animals, CABI Publishing, Wallingford, 2000, pp. 47-72.

[37] Dunnington E.A., Briles R.E., Briles W.E., Siegel P.B., Immunoresponsiveness in chickens: association of antibody production and the $\mathrm{B}$ system of the major histocompatibility complex, Poult. Sci. 75 (1996) 1156-1160.

[38] Erf G.F., Bottje W.J., Bersi T.K., Headrick M.D., Fritts C.A., Effects of dietary vitamin E on the immune system in broilers: altered proportion of CD4 T cells in the thymus and spleen, Poult. Sci. 77 (1998) 529-537.

[39] Ewald S.J., Lien Y.Y., Li L., Johnson L.W., B-haplotype control of CD4/CD8 subsets and TCR V beta usage in chicken T lymphocytes, Vet. Immunol. Immunopathol. 53 (1996) 285-301.

[40] Finkelman F.D., Shea-Donohue T., Goldhill J., Sullivan C.A., Morris S.C., Madden K.B., Gause W.C., Urban J.F. Jr., Cytokine regulation of host defence against parasitic gastrointestinal nematodes: lessons from studies with rodent models, Annu. Rev. Immunol. 15 (1997) 505-533.

[41] Gavora J.S., Disease Genetics, in: Crawford R.D. (Ed.), Genetics and Breeding of Poultry, Elsevier, Amsterdam, 1990, pp. 805-846.

[42] Gavora J.S., Spencer J.L., Studies on genetic resistance of chickens to Marek's disease-a review, Comp. Immunol. Microb. Infect. Dis. 2 (1979) 359-371

[43] Gehad A.E., Mashaly M.M., Siegel H.S., Dunnington E.A., Siegel P.B., Effects of genetic selection and MHC haplotypes on lymphocyte proliferation and interleukin-2 like activity in chicken lines selected for high and low antibody production against sheep red blood cells, Vet. Immunol. Immunopathol. 68 (1999) 13-24.

[44] Gross W.B., Siegel P.B., Environment-Genetic influences on immunocompetence, J. Anim. Sci. 66 (1988) 2091-2094.

[45] Gross W.B., Siegel P.B., Hall R.W., Domermuth C.H., DuBoise R.T., Production and persistence of antibodies in chickens to sheep erythrocytes. 2. Resistance to infectious diseases, Poult. Sci. 59 (1980) 205-210.

[46] Guillot J.F., Beaumont C., BellatifF., Mouline C., Lantier F., Colin P., Protais J., Comparison of resistance of various poultry lines to infection by Salmonella enteritidis, Vet. Res. 26(1995)81-86.
[47] Guler M.L., Jacobson N.G., Gubler U., Murphy K.M., T cell genetic background determines maintenance of IL-12 signalling: effects on $\mathrm{BALB} / \mathrm{c}$ and B10.D2 T helper cell type 1 phenotype development, J. Immunol. 159 (1997) 1767-1774.

[48] Hala K., Vainio O., Plachy J., Bock G., Chicken major histocompatibility complex congenic lines differ in the percentages of lymphocytes bearing CD4 and CD8 antigens, Anim. Genet. 22 (1991) 279-284.

[49] Han P.F.S., Smyth J.R., The influence of growth rate on the development of Marek's disease in chickens, Poult. Sci. 51 (1972) 975-985.

[50] Hartmann W., Evaluation of "Major Genes" affecting disease resistance in poultry, J. Anim. Breed. Genet. 105 (1988) 409-416.

[51] Hawken R.J., Beattie C.W., Schook L.B., Resolving the genetics of resistance to infectious diseases, Rev. Sci. Tech. Off. Int. Epizoot. 17 (1998) 17-25.

[52] Heinzel F.P., Sadick M.D., Holaday B.J., Coffman R.L., Locksley R.M., Reciprocal expression of interferon gamma or interleukin 4 during the resolution or progression of murine leishmaniasis. Evidence for expansion of distinct helper T cell subsets, J. Exp. Med. 169 (1989) 59-72.

[53] Heller E.D., Leitner G., Friedman A., Uni Z., Gutman M., Cahaner A., Immunological parameters in meat-type chicken lines divergently selected by antibody response to Escherichia coli vaccination, Vet. Immunol. Immunopathol. 34 (1992) 159-172.

[54] Holdsworth S.R., Kitching A.R., Tipping P.G., Th1 and Th2 Thelper cell subsets affect patterns of injury and outcomes in glomerulonephritis, Kidney Int. 55 (1999) 1198-1216.

[55] Holmen S.L., Salter D.W., Payne W.S., Dodgson J.R., Hughes S.H., Federspiel M.J., Soluble forms of the subgroup A avian leukosis virus $[\operatorname{ALV}(\mathrm{A})]$ receptor Tva significantly inhibit $\mathrm{ALV}(\mathrm{A})$ infection in vitro and in vivo, J. Virol. 73 (1999) 10051-10060.

[56] Hong C.C., Sevoian M., Interferon production and host resistance to type II avian (Marek's) leukosis virus (JM strain), Appl. Microbiol. 22 (1971) 818-820

[57] Hu J., Bumstead N., Burke D., Ponce de Leon F.A., Skamene E., Gros P., Malo D., Genetic and physical mapping of the natural disease resistance-associated macrophage protein 1 (Nramp) in chicken, Mamm. Genome 6 (1995) 809-815.

[58] Hu J., Bumstead N., Barrow P., Sebastiani G., Olien L., Morgan K., Malo D., Resistance to salmonellosis in the chicken is linked to NRAMP1 and TNC, Genome Res. 7 (1997) 693-704

[59] HuttF.B., Scholes J.C., Genetics of the fowl. XIII. Breed differences in susceptibility to Salmonella pullorum, Poult. Sci. 20 (1941) 342-352. 
[60] Infante-Duarte C., Kamaradt T., Th1/Th2 balance in infection, Springer Semin. Immunopathol. 21 (1999) 317-338.

[61] Kaiser P., Avian cytokines, in: Davison T.F., Morris T.R., Payne L.N. (Eds.), Poultry Immunology, Carfax Press, Abingdon, 1996, pp. 83-114.

[62] Kaspers B., Lillehoj H.S., Chicken interferonmediated induction of major histocompatibility complex class II antigens on peripheral blood monocytes, Vet. Immunol. Immunopathol. 44 (1994) 72-84

[63] Kaufman J., Co-evolving genes in MHC haplotypes: the 'rule' for non-mammalian vertebrates? Immunogenetics 50 (1999) 228-236.

[64] Kaufman J., The simple major histocompatibility complex: life and death in the face of pathogens and vaccines, Phil. Trans. R. Soc. Lond. B. 355 (2000) 1077-1084

[65] Kaufman J., Salomonsen J., B-G: we know what it is, but what does it do? Immunol. Today 13 (1992) $1-3$

[66] Kaufman J., Venugopal K., The importance of MHC for Rous sarcoma virus and Marek's disease virus - some Payne-ful consideration, Avian Pathol. 27 (1998) S82-S87.

[67] Kaufman J., Wallny H.J., Chicken MHC molecules, disease resistance and the evolutionary origin of birds, Curr. Top. Microbiol. Immunol. 212 (1996) 129-141.

[68] Kaufman J., Skjodt K., Salomonsen J., The B-G multigene family of the chicken major histocompatibility complex, Crit. Rev. Immunol. 11 (1991) 113-143.

[69] Kean R.P., Briles W.E., Cahaner A., Freeman A.E., Lamont S.J., Differences in major histocompatibility complex frequencies after multitrait, divergent selection for immunocompetence, Poult. Sci. 73 (1994) 7-17.

[70] Klasing K.C., Avian leukocytic cytokines, Poult. Sci. 73 (1994) 1035-1043.

[71] Kreukniet M.B., Nieuwland M.G., van der Zijpp A.J., Phagocytic activity of two lines of chickens divergently selected for antibody production, Vet. Immunol. Immunopathol. 44 (1995) 377- 387.

[72] Kroemer G., Bernot A., Behar G., Chause A.M., Gastinel L.N., Guillemot F., Park I., Thoraval P., Zoorob R., Auffray C., Molecular genetics of the chicken MHC: current status and evolutionary aspects, Immunol. Rev. 113 (1990) 118-145.

[73] Kronenberg M., Siu G., Hood L.E., Shastri N., The molecular genetics of the T-cell antigen receptor and T-cell antigen recognition, Annu. Rev. Immunol. 4 (1986) 529-591.

[74] Kuhnlein U., Sabour M., Gavora J.S., Fairfull R.W., Bernon D.E., Influence of selection for egg production and Marek's disease resistance on the incidence of endogenous viral genes in White Leghorns, Poult. Sci. 68 (1989) 1161-1167.

[75] Lahti J.M., Chen C.L.H., Tjoelker L.W., Pickel J.M., Schat K.A., Calnek B.W., Thompson C.B., Cooper M.D., Two distinct alpha-beta T-cell lin- eage can be distinguished by the differential usage of T-cell receptor V beta gene segments, Proc. Natl. Acad. Sci. USA 88 (1991) 10956-10960.

[76] Lakshmanan N., Lamont S.J., Rfp-Y region polymorphism and Marek's disease resistance in multitrait immunocompetence-selected chicken lines, Poult. Sci. 77 (1998) 538-541.

[77] Lambert W.V., Natural resistance to diseases in the chicken. I. The effects of selective breeding on natural resistance to fowl typhoid, J. Immunol. 23 (1932) 229-239.

[78] Lamont S.J., The chicken major histocompatibility complex in disease resistance and poultry breeding, J. Dairy Sci. 72 (1989) 1328-1333.

[79] Lamont S.J., Immunogenetics and the major histocompatibility complex, Vet. Immunol. Immunopathol. 30 (1991) 121-127.

[80] Lamont S.J., The chicken major histocompatibility complex and disease, Rev. Sci. Tech. Off. Int. Epizoot. 17 (1998) 128-142.

[81] Lanier L.L., Follow the leader: NK cell receptors for classical and non-classical MHC class I, Cell 92 (1998) 705-707.

[82] Leitner G., Uni Z., Cahaner A., Gutman M., Heller E.D., Replicated divergent selection of broiler chickens for high or low early antibody response to Escherichia coli vaccination, Poult. Sci. 71 (1992) 27-37.

[83] Li Z., Nestor K.E., Saif Y.M., Bacon W.L., Anderson J.W., Effect of selection for increased body weight on mitogenic response in turkeys, Poult. Sci. 78 (1999) 1532-1535.

[84] Li Z., Nestor K.E., Saif Y.M., Luhtala M., Flow cytometric analysis of $\mathrm{T}$ lymphocyte subpopulations in large-bodied turkey lines and a random bred control population, Poult. Sci. 79 (2000) 219-223.

[85] Lillehoj H.S., Analysis of Eimeria acervulinainduced changes in the intestinal $\mathrm{T}$ lymphocyte subpopulations in two chicken strains showing different levels of susceptibility to coccidiosis, Res. Vet. Sci. 56 (1994) 1-7.

[86] Lillehoj H.S., Ruff M.D., Bacon L.D., Lamont S.J., Jeffers T.K., Genetic control of immunity to Eimeria tenella. Interaction of MHC genes and non-MHC linked genes influences levels of disease susceptibility in chickens, Vet. Immunol. Immunopathol. 20 (1989) 135-148.

[87] Longenecker B.M., Mosmann T.R., Structure and properties of the major histocompatibility complex of the chicken. Speculations on the advantages and evolution of polymorphism, Immuno- genetics 13 (1981) 1-23.

[88] Longenecker B.M., Pazderka F., Gavora J.S., Spencer J.L., Stephens E.A., Witter R.L., Ruth R.F., Role of the major histocompatibility complex in resistance to Marek's disease: restriction of the growth of JMV-MD tumour cells in genetically resistant birds, Adv. Exp. Med. Biol. 88 (1977) 287-298 
[89] Loudovaris T., Brandon M.R., Fahey K.J., The major histocompatibility complex and genetic control of antibody response to sheep red blood cells in chickens, Avian Pathol. 19 (1990) 89-99.

[90] Lowenthal J.W., York J.J., O’Neil T.E., Rhodes S., Prowse S.J., Strom D.G., Digby M.R., In vivo effects of chicken interferon-gamma during infection with Eimeria, J. Interferon Cytokine Res. 17 (1997) 551-558.

[91] Lowenthal J.W., O’Neil T.E., David A., Strom G., Andrew M.E., Cytokine therapy: a natural alternative for disease control, Vet. Immunol. Immunopathol. 72 (1999) 183-188.

[92] Luhtala M., Chicken CD4, CD8alphabeta, and CD8alphaalpha T cell co-receptor molecules, Poult. Sci. 77 (1998) 1858-1873.

[93] Luhtala M., Tregaskes C.A., Young J.R., Vainio O., Polymorphism of chicken CD8-alpha, but not CD8-beta, Immunogenetics, 46 (1997) 369- 401.

[94] Lunney J.K., Cytokines orchestrating the immune response, Rev. Sci. Tech. Off. Int. Epizoot. 17 (1998) 84-94.

[95] Malo D., Skamene E., Genetic control of host resistance to infection, Trends Genet. 10 (1994) 365-371.

[96] Mansikka A., Jalkanen S., Sandberg M., Granfors K., Lassila O., Toivanen P., Bursectomy of chicken embryos at 60 hours of incubation leads to an oligoclonal B cell compartment and restricted $\mathrm{Ig}$ diversity, J. Immunol. 145 (1990) 3601-3609.

[97] Miller M.M., Goto R., Young S., Liu J., Hardy J., Antigens similar to major histocompatibility complex B-G are expressed in the intestinal epithelium in the chicken, Immunogenetics 32 (1990) 45-50.

[98] Moller L.B., Kaufman J., Verland S., Salomonsen J., Avila D., Lambris J.D., Skjodt $\mathrm{K}$, Variations in the cytoplasmic region account for the heterogeneity of the chicken MHC class I (B-F) molecules, Immunogenetics 34 (1991) 110-120.

[99] Mombaerts P., Iacomini J., Johnson R.S., Herrup K., Tonegawa S., Papaioannou V.E., RAG-1 deficient mice have no mature $\mathrm{T}$ and $\mathrm{B}$ lymphocytes, Cell 68 (1992) 869-877.

[100] Nestor K.E., Saif Y.M., Zhu J., Noble D.O., Research note: influence of growth selection in turkeys on resistance to Pasteurella multocida, Poult. Sci. 75 (1996) 1161-1163.

[101] Oksenberg J.R., Steinman L., The role of the MHC and T-cell receptor in susceptibility to multiple sclerosis, Curr. Opin. Immunol. 2 (1989) 619-621.

[102] Parmentier H.K., Kreukniet M.B., Goeree B., Davison T.F., Jeurissen S.H.M., Harmsen E.G.M., Nieuwland M.G.B., Differences in distribution of lymphocyte antigens in chicken lines divergently selected for antibody responses to sheep red blood cells, Vet. Immunol. Immuno- pathol. 48 (1995) 155-168.

[103] Peleg B.A., Heller E.D., Pitcovsky J., The ontogeny of the humoral response to $E$. coli vaccine and sheep red blood cells in young chicks, Avian Pathol. 14 (1985) 471-481.

[104] Pinard M.H., Janss L.L, Maatman R. Noordhuizen J.P., van der Zijpp A.J., Effect of divergent selection for immune responsiveness and of major histocompatibility complex on resistance to Marek's disease in chickens, Poult. Sci. 72 (1993) 391- 402 (erratum 72 (1993) 1192).

[105] Pinard M.H., Siegel P.B., Lamont S.J., Lessons from selection experiments on immune response in the chicken, Poult. Avian Biol. Rev. 9 (1998) 125-141.

[106] Plachy J., Pink J.R.L., Hála K., Biology of the chicken MHC (B complex), Crit. Rev. Immunol. 12 (1992) 47-79.

[107] Puzzi J.V., Bacon L.D., Dietert R.R., B-congenic chickens differ in macrophage inflammatory responses, Vet. Immunol. Immunopathol. 26 (1990) 13-30.

[108] Qureshi M.A., Havenstein G.B., A comparison of the immune performance of a 1991 commercial broiler with a 1957 random bred strain when fed "typical" 1957 and 1991 broiler diets, Poult. Sci. 73 (1994) 1805-1812.

[109] Qureshi M.A., Dietert R.R., Bacon L.D., Chemotactic activity of chicken blood mononuclear leukocytes from 15I5-B-congenic lines to bacterial-derived chemoattractants, Vet. Immunol. Immunopathol. 19 (1988) 351-360.

[110] Ratcliffe M.J., Jacobsen K.A., Rearrangement of immunoglobulin genes in chicken B cell development, Semin. Immunol. 6 (1994) 175-184.

[111] Rees M.J., Nordskog A.W., Genetic control of serum immunoglobulin $\mathrm{G}$ levels in the chicken, J. Immunogenet. 8 (1981) 425-431.

[112] Reynaud C.A., Bertocci B., Dahan A., Weill J.C., Formation of the chicken B-cell repertoire: ontogenesis, regulation of Ig gene rearrangement, and diversification by gene conversion, Adv. Immunol. 57 (1994) 353-378.

[113] Roitt I.M., Fundamental Immunology, Raven Press, New York, 1993.

[114] Rose N.R., Avian models of autoimmune disease: lessons from the birds, Poult. Sci. 73 (1994) 984-990

[115] Rothschild M.F., Selection under challenging environment, in: Owen J.B., Axford R.F.E. (Eds.), Breeding for disease resistance in farm animals, CABI Publishing, Wallingford, 1991, pp. 73-85.

[116] Rothschild M.F., Skow L., Lamont S.J., The major histocompatibility complex and its role in disease resistance and immune responsiveness, 
in: Axford R.F.E., Bishop S.C., Nicholas F.W., Owen J.B. (Eds.), Breeding for disease resistance in farm animals, CABI publishing, Wallingford, 2000, pp. 73-106.

[117] Sacco R.E., Nestor K.E., Saif Y.M., Tsai H.J., Patterson R.A., Effects of genetic selection for increased body weight and sex of poults on antibody response of turkeys to Newcastle disease virus and Pasteurella multocida vaccines, Avian Dis. 38 (1994) 33-36.

[118] Salomonsen J., Dunon D., Skjodt K., Thorpe D., Vainio O., Kaufman J., Chicken major histocompatibility complex-encoded B-G antigens are found on many cell types that are important for the immune system, Proc. Natl. Acad. Sci. USA 88 (1991) 1359-1363.

[119] Schat K.A., Taylor R.L., Brils W.E., Resistance to Marek's disease in chickens with recombinant haplotypes of the major histocompatibility (B) complex, Poult. Sci. 73 (1994) 502-508

[120] Schierman L.W., Collins W.M., Influence of the major histocompatibility complex on tumour regression and immunity in chickens, Poult. Sci. 66 (1987) 812-818.

[121] Siegel P.B., Gross E.B., Production and persistence of antibodies in chicken to sheep erythrocytes. I. Directional selection, Poult. Sci. 59 (1980) 1-5.

[122] Siegel P.B., Larsen A.S., Larsen C.T., Dunnington E.A., Resistance of chickens to an outbreak of necrotic enteritis as influenced by major histocompatibility genotype and background genome, Poult. Sci. 72 (1993) 11891191.

[123] Singh V.K., Mehrotra S., Agarwal S.S., The paradigm of Th1 and Th2 cytokines: its relevance to autoimmunity and allergy, Immunol. Res. 20 (1999) 147-161.

[124] Skamene E., Gros P., Forget A., Kongshavn P.A.I., St Charles C., Taylor B.A., Genetic regulation of resistance to intracellular pathogens, Nature 297 (1982) 506-509.

[125] Smith E.J., Fadly A.M., Crittenden L.B., Interactions between endogenous virus loci ev6 and ev21. 2. Congenital transmission of EV21 viral products to female progeny from slow-feathering dams, Poult. Sci. 69 (1990) 1251-1256.

[126] Street N.E., Mosmann T.R., Functional diversity of T lymphocytes due to secretion of different cytokine patterns, FASEB J. 5 (1991) 171-177.

[127] Taylor R.L. Jr., Cotter P.F., Wing T.L., Briles W.E., Major histocompatibility (B) complex and sex effects on the phytohemagglutinin wattle response, Anim. Genet. 18(1987) 343-350.

[128] Tjoelker L.W., Carlson L.M., Lee K., Lahti J., McCormack W.T., Leiden J.M., Chen C.L., Cooper M.D., Thompson C.B., Evolutionary conservation of antigen recognition: the chicken
T-cell receptor beta chain, Proc. Natl. Acad. Sci. USA 87 (1990) 7856-7860.

[129] Uni Z., Sklan D., Haklay N., Yonash N., Heller D., Response of three class-IV major histocompatibility complex haplotypes to Eimeria acervulina in meat-type chickens, Br. Poult. Sci. 36 (1995) 555-561.

[130] Van der Zijpp A.J., Nieuwland M.G., The Biozzi Model applied to the chicken, Curr. Top. Vet. Med. Anim. Sci. 52 (1989) 160-168.

[131] Vidal S.M., Pinner E., Lepage P., Gauthier S., Gros P., Natural resistance to intracellular infections: Nramp1 encodes a membrane phosphoglycoprotein absent in macrophages from susceptible (Nramp1 D169) mouse strains, J. Immunol. 157 (1996) 3559-3568

[132] Wakenell P.S., Miller M.M., Goto R.M., Gauderman W.J., Briles W.E., Association between the $R f p-Y$ haplotype and the incidence of Marek's disease in chickens, Immunogenetics 44 (1996) 242-245.

[133] White E.C., Briles W.E., Briles R.W., Taylor R.L. Jr., Response of 6 major histocompatibility (B) complex recombinant haplotypes to Rous sarcomas, Poult. Sci. 73 (1994) 836-842.

[134] Wigley P., Bumstead N., Barrow P.A., Increased killing of intracellular Salmonella gallinarum by macrophages from Salmonella resistant inbred chicken lines, in: Abstracts and proceedings of XXI World's Poultry Congress and 6th International Symposium on Marek's Disease, August 20-24, 2000, W13.07, Montreal, Canada.

[135] Wilson T.J., Water J.V., Mohr F.C., Boyd R.L. Ansari A., Wick G., Gershwin M.E., Avian Scleroderma: evidence for quantitative and qualitative $\mathrm{T}$ cell defects, J. Autoimmun. 5 (1992) 261-276.

[136] Yonash N., Leitner G., Waiman R., Heller E.D., Cahaner A., Genetic differences and heritability of antibody response to Escherichia coli vaccination in young broiler chicks, Poult. Sci. 75 (1996) 683-690.

[137] Yoo B.H., Sheldon B.L., Association of the major histocompatibility complex with avian leukosis virus infection in chickens, Br. Poult. Sci. 33 (1992) 613-620.

[138] Young J.A., Avian leukosis virus-receptor interactions, Avian Pathol. 27 (1998) S21-S25.

[139] Yun C.H., Lillehoj H.S., Choi K.D., Eimeria tenella infection induces local gamma interferon production and intestinal lymphocyte subpopulation changes, Infect. Immun. 68 (2000) 1282-1288.

[140] Zekarias B., Landman W.J.M., Tooten P.C.J., Gruys E., Leukocyte responses in two breeds of layer chicken that differ in susceptibility to induced amyloid arthropathy, Vet. Immunol. Immunopathol. 77 (2000) 55-69. 